ARAÚJO, CMM; SILVA FILHO, DF; TICONA-BENAVENTE, CA; BATISTA, MRA. 2018. Morphoagronomic characteristics display high genetic diversity in Murupi chili pepper landraces. Horticultura Brasileira 36: 083-087. DOI - http://dx.doi.org/10.1590/S0102-053620180114

\title{
Morphoagronomic characteristics display high genetic diversity in Murupi chili pepper landraces
}

\author{
Cecilia MM Araújo; Danilo F Silva Filho; César Augusto Ticona-Benavente; Manoel Ronaldo A Batista
}

Instituto Nacional de Pesquisas da Amazônia (INPA), Manaus-AM, Brazil;_ceciliaagro@gmail.com; danilo@inpa.gov.br; cesar.benavente@ gmail.com; ronaldo@inpa.gov.br

\begin{abstract}
Murupi chili pepper is a hot Amazonian pepper that has been used as flavoring in the region, yet its diversity is unknown. This paper aims to assess the diversity in 20 landraces from Peruvian, Colombian, and Brazilian Amazon. The experiment was installed in Manaus-AM, using a randomized complete block design with three replicates and five plants per plot. Analyses of variance showed significant differences for all nine descriptors. Fruit yield showed, in average, to be 208.08 fruits per plant, tantamount to 381.44 g per plant. Given $50 \%$ of relative distances estimated by generalized Mahalanobis distances and, nearest neighbor clustering, they displayed six groups. Cluster I comprised $50 \%$ of the landraces. Clusters IV, V and VI were represented by ' 8 ' (Putumayo, Colombia), '27' (Yurimaguas, Peru) and '24' (Jutaí-AM, Brazil), respectively. The highest yielding landrace showed to be '17' (Manicoré-AM, Brazil), bearing 685.5 fruits and $1.92 \mathrm{~kg}$ per plant. Our findings suggest Murupi pepper may possibly be improved by selection and/ or hybridization.
\end{abstract}

Keywords: Capsicum chinense, Amazon pepper, hot pepper, Amazon vegetable, pre-breeding.

\section{RESUMO}

Caracteres morfoagronômicos revelam elevada diversidade genética das variedades crioulas de pimenta Murupi

A pimenta Murupi é muito utilizada na região Amazônica como condimento, mas ainda se desconhece sua diversidade. $\mathrm{O}$ objetivo deste trabalho foi avaliar 20 acessos procedentes da Amazônia peruana, colombiana e brasileira. Para tanto foi conduzido um experimento em Manaus-AM, utilizando o delineamento de blocos completos ao acaso com três repetições e cinco plantas por parcela. As análises da variância mostraram que existe diferença significativa para todos os nove descritores. A produtividade média de frutos foi 208,08 frutos por planta o que equivale a $381,44 \mathrm{~g}$ por planta. Considerando $50 \%$ das distâncias relativas, obtidas a partir das distâncias generalizadas de Mahalanobis e o método de agrupamento do vizinho mais próximo, foram encontrados seis grupos. O grupo I foi composto por $50 \%$ dos acessos e os grupos IV, V e VI foram compostos por ' 8 ' (Putumayo, Colombia), '27' (Yurimaguas, Peru) e '24' (Jutaí-AM, Brasil), respectivamente. A maior produção de frutos foi do acesso '17' (Manicoré-AM, Brasil) com 685,50 frutos por planta e 1,92 kg por planta. Estes resultados indicam que a pimenta Murupi pode ser melhorada via seleção ou fazendo cruzamentos.

Palavras-chave: Capsicum chinense, pimenta amazônica, pimenta, hortaliça amazônica, pre-melhoramento.

Received on November 10, 2016; accepted on September 20, 2017

$\mathrm{M}$ urupi chili pepper (Capsicum chinense) (Photo 1) is greatly appreciated in the Amazonian region, because it exhibits a special, low pungency and sweetness combination. It grows up to $1.50 \mathrm{~m}$ high, containing a high content of terpens, esters, and sesquiterpens in volatile compounds (Bogusz Junior et al., 2012, 2015). They also display a wide diversity of shape, size, and coloring in the fruits. It may be called the most Brazilian pepper when compared to other Capsicum genera (Silva Filho et al., 2013), because it is well adapted to several Brazilian soils and climates (Lannes et al., 2007).

Family farmers are currently cultivating Capsicum landraces in the Amazon, yet Amazonian peppers have been undergoing genetic drift on account of being replaced by other crops or desertion of field activities.

Diversity studies can help to understand the genetic diversity level, identify useful genes and, at the same time assist on selecting genitors (Cruz \& Regazzi, 2001). Multivariate analyses, such as distances and cluster analyses are frequently used to assess the diversity of quantitative and qualitative characters. These approaches were useful to characterize various species, such as snap bean (Peixoto et al., 2002); melon (Rizzo \& Braz, 2000); wheat (Bertan et al., 2006), pepper (Sudré et al., 2005; Toquica et al., 2003; Zewdie et al., 2004); oat (Kurek et al., 2002) and maize (Coimbra et al., 2010).

In general, there are few studies addressing Amazon peppers. Antonious et al. (2009) have reported a wide diversity among $63 C$. chinense accessions from different countries, some of them from Brazil. Other researchers have detected significant 
diversity in 20 non-pungent Amazon landraces (C. chinense) (Batista et al., 2013). Diversity was detected on some Murupi chili pepper landraces from the upper Rio Negro (Fonseca et al., 2008). However, there are many landraces to be collected, and have their diversity assessed in the Amazon basin.

Our team has performed collections of various pepper types from the Amazon region for several years. The germplasm has been stored at the National Research Institute of Amazonia (INPA). This paper assesses the genetic diversity of 20 Murupi chili pepper landraces, most from the Amazonian region in Brazil, and some from Peru and Colombia.

\section{MATERIAL AND METHODS}

Twenty Murupi chili pepper landraces from the INPA's germplasm bank (Manaus, Brazil), were assessed to determinate their diversity level. They originated from 20 different sites in the Amazon region (Figure 1).

The experiment was conducted at INPA's 'Alejo von der Pahlen' experimental station $\left(2^{\circ} 59^{\prime} 48^{\prime \prime} \mathrm{S}\right.$, $60^{\circ} 1$ ' $22^{\prime}$ 'W, altitude $60 \mathrm{~m}$ ). The Manaus climate is characterized as 'Af' type, according to Köppen climate ranking. In 2013, rainfall was equivalent to $2,732 \mathrm{~mm}$, with $63 \mathrm{~mm}$ and $408 \mathrm{~mm}$ in the months with the lightest (October) and the heaviest rainfall (March), respectively. The low rainfall season extended from August $(93 \mathrm{~mm})$ to October $(63 \mathrm{~mm})$. The mean annual temperature was $26.8^{\circ} \mathrm{C}$, ranging from 20.0 to $38.2^{\circ} \mathrm{C}$ with mean daily relative humidity of $88.7 \%$ (Scarazati, 2016).

The seedlings were started in a greenhouse using plastic cups filled with autoclaved organic compost $\left(120^{\circ} \mathrm{C}\right.$ during $2 \mathrm{~h}$ ). Three seeds were sown in every cup and, when the plants had developed two true leaves they were rouged so as to attain the strongest seedling per cup. Next, $15 \mathrm{~cm}$ high seedlings were transplanted in the field at $1.5 \mathrm{~m}$ between rows and $1.0 \mathrm{~m}$ apart within rows, following a randomized complete block design with three replicates and five plants per plot. The soil analysis results showed $\mathrm{pH}$ in water $=5.4$; organic material $=20.8 \mathrm{~g} \mathrm{~kg}^{-1} ; \mathrm{C}=$ $12.91 \mathrm{~g} \mathrm{~kg}^{-1} ; \mathrm{N}=0,64 \mathrm{~g} \mathrm{~kg}^{-1} ; \mathrm{P}=100.91$ $\mathrm{mg} \mathrm{kg}{ }^{-1} ; \mathrm{K}=10.01 \mathrm{mg} \mathrm{kg}^{-1} ; \mathrm{Ca}=1.36$ cmolc kg-1 $; \mathrm{Mg}=35.1 \mathrm{mg} \mathrm{kg}^{-1} ; \mathrm{Fe}=7.4$ $\mathrm{mg} \mathrm{kg}^{-1} ; \mathrm{Mn}=6.3 \mathrm{mg} \mathrm{kg}^{-1} ; \mathrm{Zn}=5.2 \mathrm{mg}$ $\mathrm{kg}^{-1}$.

Each hole was $20 \mathrm{~cm}$ wide and deep. Each hole was fertilized with 2 $\mathrm{kg}$ of organic compost, $50 \mathrm{~g}$ of triple superphosphate, $40 \mathrm{~g}$ of potassium chlorate and $10 \mathrm{~g}$ of urea, as well. After transplanting to the open field, complementary fertilization with $10 \mathrm{~g}$ of urea per plant and weedings were performed every fortnight, until the start of fructification stage. In this experiment, no pesticide was used. The harvesting point was determined when the fruits displayed yellowish coloring.

The assessments were performed following the descriptors recommended by the International Plant Genetic Resources Institute (IPGRI, 1995). Nine quantitative descriptors, such as stem diameter (SD) $1.0 \mathrm{~cm}$ above ground, plant height $(\mathrm{PH})$ after three months of transplanting, canopy diameter (CD), fruit length (FL), fruit diameter (FD), fruit pericarp thickness (FPT), fruit number per plant (FNP), mean fruit mass (MFM) and fruit mass per plant (FMP), were measured. Fruit data, such as FL, FD, FPT were obtained from the 10 first fruits per plant.

The analyses of variance and Skott-Knott tests were performed at $5 \%$ of probability. nearest neighbor method and generalized distances of Mahalanobis $\left(\mathrm{D}^{2}\right)$ were used to calculate clustering and distances between landraces, respectively. All analyses were performed in GENES Software (Cruz, 2008).

\section{RESULTS AND DISCUSSION}

Analyses of variance detected significant differences for all descriptors showing wide genetic diversity within Murupi chili pepper landraces (Table 1). Mean fruit mass (MFM) exhibited the highest coefficient of variation $(18 \%)$, indicating a high experimental quality. Therefore, quality data and interpretations are reliable.

The descriptors are associated with vegetative development indicators such as plant height (PH), stalk diameter (SD) and canopy diameter $(\mathrm{CD})$, ranged from 48.06 to $100.12 \mathrm{~cm} ; 1.80$ to $3.36 \mathrm{~cm}$ and 57.8 to $111.65 \mathrm{~cm}$, respectively. Plant height ranged from 55.08 to $100.12 \mathrm{~cm}$, which is desirable for manual harvesting or landscaping (Neitzke et al., 2010). High SD and CD may lead to increased fruit yield, like landrace ' 17 ', which showed the highest fruit yield. However, this is not always true because landrace ' 6 ' had high stem height and diameter, but poor fruit mass per plant (116 g).

On the other hand, fruit descriptors such as fruit length (FL), diameter (FD) and pericarp thickness (FPT) had the following range: 1.40 to $6.23 \mathrm{~cm}$, 5.46 to $14.38 \mathrm{~mm}$ and 0.57 to $1.66 \mathrm{~mm}$, respectively. In another type of nonpungent pepper (C. chinense) called 'Pimenta de cheiro' Domenico et al. (2012) found ranges for FL (2.1 to 7.7 $\mathrm{cm}$ ) and FD (11 to $25 \mathrm{~mm}$ ) showing that Murupi chili pepper tends to be smaller-sized than 'Pimenta de cheiro'. In another research with 330 accessions of $C$. chinense, Jarret \& Berke (2008) found high amplitude for FL (0.8 to 11.0 $\mathrm{cm}$ ) and FD (6 to $40 \mathrm{~mm}$ ), since these accessions were likely to have included many pepper types. In non-pungent Amazonian peppers (Capsicum spp.), Batista et al. (2013) found amplitude from 2.04 to $6.02 \mathrm{~cm}, 7.7$ to $38.9 \mathrm{~mm}$ and 0.77 to $2.30 \mathrm{~mm}$ for FL, FD and FPT respectively. Therefore, in general, our findings showed low amplitude for FL, FD and FPT. It suggests that probably Murupi pepper is one of the smallest peppers of Capsicum chinense species.

On the other hand, the descriptors related to fruit yield, such as fruit number per plant (FNP), fruit mean mass (FMM) and fruit mass per plant (FMP) exhibited amplitudes from 53,0 to $685.5 ; 0.41$ to $2.96 \mathrm{~g}$ and 67.96 to $1919.4 \mathrm{~g}$, respectively. It is interesting to note landrace ' 17 ' displayed the highest mean values for these three descriptors. This landrace was from the municipality of Manicoré $\left(5^{\circ} 48^{\prime} \mathrm{S}, 61^{\circ} 17^{\prime} \mathrm{W}\right)$, which has a climate similar to that of Manaus (2 $2^{\circ} 59^{\prime} 48^{\prime \prime} \mathrm{S}, 60^{\circ} 1$ '22.4”'W). In general, 
Table 1. Descriptors means of Murupi pepper landraces (Capsicum chinense) collected from the Amazon basin. Manaus, INPA, 2013.

\begin{tabular}{|c|c|c|c|c|c|c|c|c|c|}
\hline Landraces & $\begin{array}{l}\text { Plant } \\
\text { height } \\
(\mathrm{cm})\end{array}$ & $\begin{array}{c}\text { Stalk } \\
\text { diameter } \\
(\mathrm{cm})\end{array}$ & $\begin{array}{c}\text { Canopy } \\
\text { diameter } \\
(\mathrm{cm})\end{array}$ & $\begin{array}{c}\text { Fruit } \\
\text { length (cm) }\end{array}$ & $\begin{array}{c}\text { Fruit } \\
\text { diameter } \\
(\mathrm{cm})\end{array}$ & $\begin{array}{c}\text { Fruit pericarp } \\
\text { thickness } \\
(\mathbf{m m})\end{array}$ & $\begin{array}{c}\text { Fruit } \\
\text { mean } \\
\text { mass (g) }\end{array}$ & $\begin{array}{c}\text { Fruit } \\
\text { number } \\
\text { per plant }\end{array}$ & $\begin{array}{c}\text { Fruit } \\
\text { mass per } \\
\text { plant (g) }\end{array}$ \\
\hline 3 & $57.54 \mathrm{k}$ & $2.44 \mathrm{e}$ & 68.921 & $4.13 \mathrm{e}$ & 9.631 & $1.38 \mathrm{~g}$ & $1.64 \mathrm{c}$ & $318.25 \mathrm{c}$ & $525.84 \mathrm{e}$ \\
\hline 4 & $68.22 \mathrm{~g}$ & $2.82 \mathrm{c}$ & $73.06 \mathrm{k}$ & $3.00 \mathrm{f}$ & 9.691 & $1.40 \mathrm{f}$ & $1.48 \mathrm{c}$ & $136.00 \mathrm{~m}$ & $194.74 j$ \\
\hline 5 & $89.32 \mathrm{c}$ & $3.16 \mathrm{~b}$ & $63.12 p$ & $1.40 \mathrm{~h}$ & $5.46 \mathrm{p}$ & $0.57 \mathrm{n}$ & $0.41 \mathrm{~d}$ & $87.50 \mathrm{q}$ & $67.96 n$ \\
\hline 6 & $100.12 \mathrm{a}$ & $3.36 \mathrm{a}$ & $95.31 \mathrm{~d}$ & $2.38 \mathrm{~g}$ & $10.88 \mathrm{~h}$ & $1.23 \mathrm{k}$ & $1.33 \mathrm{c}$ & $87.50 \mathrm{q}$ & $116.21 \mathrm{~m}$ \\
\hline 7 & $67.85 \mathrm{~g}$ & $3.21 \mathrm{~b}$ & $58.53 \mathrm{~s}$ & $4.08 \mathrm{e}$ & $12.46 \mathrm{f}$ & $1.48 \mathrm{c}$ & $2.40 \mathrm{a}$ & $124.00 \mathrm{n}$ & $297.60 \mathrm{~h}$ \\
\hline 8 & $77.49 \mathrm{f}$ & $2.61 \mathrm{~d}$ & $76.31 \mathrm{~h}$ & $3.22 \mathrm{f}$ & 9.581 & $1.32 \mathrm{i}$ & $1.44 \mathrm{c}$ & 118.750 & $167.15 \mathrm{k}$ \\
\hline 9 & $87.41 \mathrm{~d}$ & $3.14 \mathrm{~b}$ & $97.32 \mathrm{c}$ & $3.27 \mathrm{f}$ & $9.2 \mathrm{~m}$ & $1.29 \mathrm{j}$ & $1.24 \mathrm{c}$ & $112.51 \mathrm{p}$ & 139.411 \\
\hline 10 & $85.42 \mathrm{e}$ & $3.13 b$ & $62.18 \mathrm{q}$ & $3.14 \mathrm{f}$ & $10.07 \mathrm{k}$ & 1.201 & $1.14 \mathrm{c}$ & $117.75 \mathrm{o}$ & 134.241 \\
\hline 11 & $87.14 d$ & $2.87 \mathrm{c}$ & $97.78 b$ & $3.33 \mathrm{f}$ & $14.38 \mathrm{a}$ & $1.66 \mathrm{a}$ & $2.96 \mathrm{a}$ & $53.00 \mathrm{r}$ & 156.981 \\
\hline 12 & $76.88 \mathrm{f}$ & $2.94 \mathrm{c}$ & $68.1 \mathrm{n}$ & $2.57 \mathrm{~g}$ & 7.350 & $1.17 \mathrm{~m}$ & $0.76 \mathrm{~d}$ & $182.00 \mathrm{j}$ & 148.01 \\
\hline 15 & $58.72 \mathrm{k}$ & $3.35 \mathrm{a}$ & $57.80 \mathrm{t}$ & $3.09 \mathrm{f}$ & $10.49 \mathrm{i}$ & $1.47 \mathrm{~d}$ & $1.47 \mathrm{c}$ & 157.001 & $236.28 \mathrm{i}$ \\
\hline 16 & $48.81 \mathrm{~m}$ & $2.71 \mathrm{~d}$ & $78.38 \mathrm{~g}$ & $4.23 \mathrm{e}$ & $8.31 \mathrm{n}$ & $1.39 \mathrm{~g}$ & $1.99 \mathrm{~b}$ & $165.33 \mathrm{k}$ & $296.36 \mathrm{~h}$ \\
\hline 17 & $98.21 b$ & $3.11 \mathrm{~b}$ & $111.65 \mathrm{a}$ & $5.42 \mathrm{c}$ & $10.21 \mathrm{j}$ & $1.57 \mathrm{~b}$ & $2.80 \mathrm{a}$ & $685.50 \mathrm{a}$ & $1919.40 \mathrm{a}$ \\
\hline 18 & $62.43 \mathrm{i}$ & $2.11 \mathrm{~g}$ & $75.21 \mathrm{i}$ & $6.12 \mathrm{a}$ & $11.21 \mathrm{~g}$ & $1.42 \mathrm{e}$ & $1.44 \mathrm{c}$ & $215.00 \mathrm{~h}$ & $308.60 \mathrm{~h}$ \\
\hline 20 & $65.22 \mathrm{~h}$ & $1.91 \mathrm{i}$ & $82.34 \mathrm{e}$ & $5.87 \mathrm{~b}$ & $10.30 \mathrm{j}$ & $1.37 \mathrm{~h}$ & $1.32 \mathrm{c}$ & $262.24 f$ & $346.12 \mathrm{~g}$ \\
\hline 22 & $58.03 \mathrm{k}$ & $2.28 \mathrm{f}$ & $68.48 \mathrm{~m}$ & $4.91 \mathrm{~d}$ & $13.20 \mathrm{~d}$ & $1.28 \mathrm{j}$ & $1.83 \mathrm{~b}$ & $191.99 \mathrm{i}$ & $363.57 \mathrm{~g}$ \\
\hline 24 & $66.04 \mathrm{~h}$ & $2.16 \mathrm{~g}$ & $81.20 \mathrm{f}$ & $6.23 a$ & $13.50 \mathrm{c}$ & $1.40 \mathrm{f}$ & $1.75 b$ & $243.44 \mathrm{~g}$ & $426.02 \mathrm{f}$ \\
\hline 25 & $60.02 j$ & $1.80 \mathrm{i}$ & $73.82 \mathrm{j}$ & $6.11 \mathrm{a}$ & $12.89 \mathrm{e}$ & $1.38 \mathrm{~g}$ & $2.10 \mathrm{~b}$ & $278.41 \mathrm{e}$ & $584.66 \mathrm{c}$ \\
\hline 26 & 55.081 & $2.01 \mathrm{~h}$ & $59.34 \mathrm{k}$ & $5.82 b$ & $13.86 \mathrm{~b}$ & $1.37 \mathrm{~h}$ & $1.97 \mathrm{~b}$ & $324.42 b$ & $638.95 b$ \\
\hline 27 & $48.06 \mathrm{~m}$ & $2.02 \mathrm{~h}$ & $66.42 \mathrm{o}$ & $5.77 \mathrm{~b}$ & $14.32 \mathrm{a}$ & $1.38 \mathrm{~g}$ & $1.86 \mathrm{~b}$ & $301.46 \mathrm{~d}$ & $560.71 d$ \\
\hline Mean & 70.90 & 2.65 & 75.76 & 4.20 & 10.85 & 1.33 & 1.66 & 208.08 & 381.44 \\
\hline CV (\%) & 0.81 & 2.66 & 0.30 & 4.80 & 0.73 & 0.47 & 18.25 & 1.26 & 3.07 \\
\hline
\end{tabular}

Means with the same letter in the column indicate non-significant differences by Scott-Knott test $(\mathrm{P}<0.05)$.

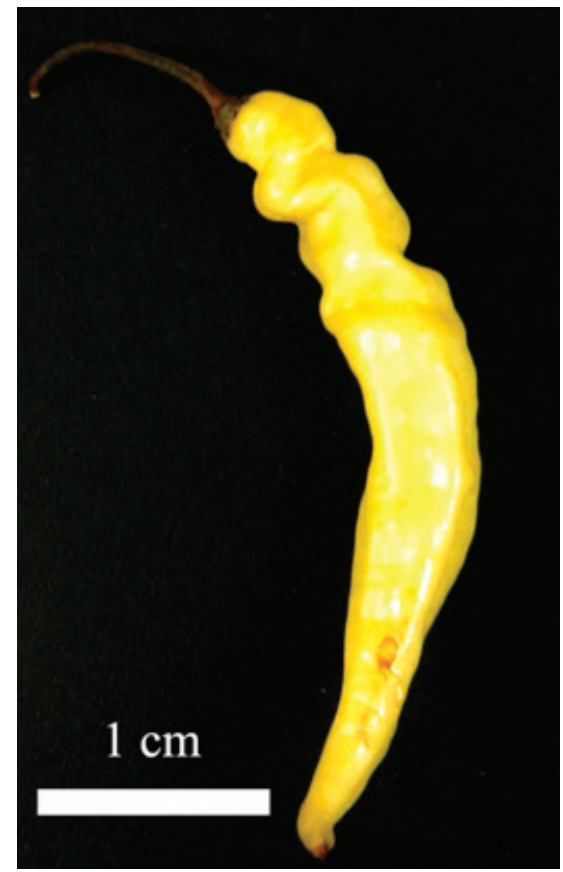

Photo 1. Murupi chili pepper pod. Manaus 2013 (own source). Manaus, INPA, 2013. the other landraces had a poor fruit yield in Manaus weather conditions; hence this landrace could be selected for further improvement.

The genetic dissimilarity values were estimated by generalized distances of Mahalanobis $\left(\mathrm{D}^{2}\right)$ (Table 2). These distances are recommended when the assessed characters present different scales. Comparing the distances, we found maximum distance to have been between landraces 17 (Manicoré-AM, Brazil) and 5 (São Sebastião do Umatumã-AM, Brazil). Presumably, they are from different sites or domestication centers. It may be accounted for by the strong geographical isolation brought about by the Madeira, Amazon and Uatumã Rivers. The Madeira and Uatumã Rivers are major tributaries to the middle Amazon River. The Uatumã River is located 200 $\mathrm{km}$ downriver from the Amazon and
Madeira Rivers confluence. These geographical characteristics may lead to isolation of landraces, similar to allopatric evolution. Conversely, the minimum distance was found between landraces 4 (São Gabriel da CachoeiraAM, Brazil) and 8 (Putumayo, Colombia). Geographically, these sites are not far from each other because São Gabriel da Cachoeira is on the border with Colombia. This suggests that there may be seed interchange between the upper Rio Negro region of Brazil and the southern areas of Colombia.

Six groups were found through nearest neighbor cluster method based on Mahalanobis distances (Figure 2). The clusters were formed with a $50 \%$ relative distance. We chose this relative distance to increase the probability of significant differences between groups.

The clustering results were plotted according to their geographical 
Table 2. Some generalized Mahalabinobis distances (D2) among Murupi chili pepper landraces (Capsicum chinense) from Amazonian basin. Manaus, INPA, 2013.

\begin{tabular}{lrcr}
\hline Landraces comparison & > Distance & $\begin{array}{c}\text { Landraces } \\
\text { comparison }\end{array}$ & < Distance \\
\hline 3 vs 17 & 72291.92 & 3 v 25 & 2794.83 \\
4 vs 17 & 94036.35 & 4 vs 8 & 870.52 \\
5 vs 17 & 146136.02 & 5 vs 12 & 12206.32 \\
6 vs 17 & 82891.33 & 6 vs 9 & 1492.94 \\
7 vs 17 & 120325.08 & 7 vs 15 & 1226.95 \\
8 vs 17 & 92279.98 & 10 vs 12 & 2844.54 \\
9 vs 17 & 74379.56 & 11 vs 6 & 7593.40 \\
10 vs 17 & 118289.39 & 16 vs 4 & 2526.37 \\
11 vs 17 & 84924.12 & 17 vs 20 & 60365.82 \\
12 vs 17 & 99791.25 & 18 vs 20 & 1622.91 \\
15 vs 17 & 119888.51 & 22 vs 18 & 1863.22 \\
16 vs 17 & 83704.22 & 24 vs 20 & 1789.85 \\
18 vs 17 & 76423.65 & 25 vs 18 & 1194.01 \\
20 vs 17 & 60365.82 & & \\
22 vs 17 & 91097.08 & & \\
24 vs 17 & 62848.30 & & \\
25 vs 17 & 66492.41 & & \\
27 vs 17 & 88562.46 & & \\
\hline Distances mean & 80297.14 & & \\
\hline
\end{tabular}

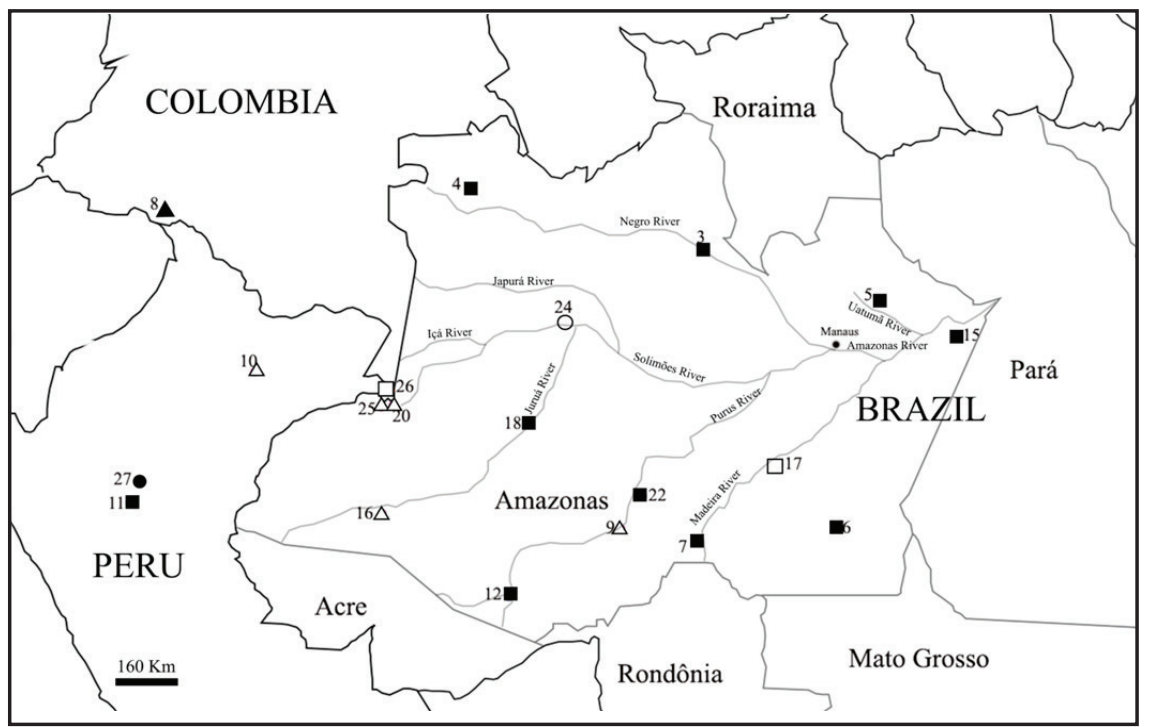

Figure 1. Geographical collection sites of Murupi chili pepper landraces (Capsicum chinense). Brazil: 3. Barcelos-AM; 4. São Gabriel da Cachoeira-AM; 5. São Sebastião do Uatumã-AM; 6. Apuí-AM; 7. Humaitá-AM; 9. Lábrea-AM; 12. Boca do Acre-AM; 15. Barreirinha-AM; 16. Eirunepé-AM; 17. Manicoré-AM; 18. Carauari-AM; 20. Benjamin Constant-AM; 22. Canutama-AM; 24. Jutaí-AM; 25. Atalaia do Norte-AM. Colombia: 8. Putumayo and 26. Letícia. Peru: 10. Iquitos; 11. Tarapoto and 27. Yurimaguas. Same icons indicate that these landraces are included in a cluster, which was determinated based on $50 \%$ of relative distances obtained from generalized Mahalanobis distances. Chart from César Ticona-Benavente based on Google Maps, 2015. collection site (Figure 1), with each group being differently colored. Cluster I (Figure 1, bold square) included about $50 \%$ of the total landraces (' 3 ', ' 4 ', ' 5 ', '6', '7', '11', '12', '15', '18' and '22'). In this cluster, the landraces' collection locals were extremely diverse, from Amazonas State (Brazil) to Tarapoto (Peru). These findings support the theory of interchanging seeds being frequent throughout the Amazon region, especially between Peru and Brazil.

Cluster II (Figure 1, unbold triangle) was equivalent to $25 \%$ of the studied landraces ('9', '10', '16', '20', and '25'). They are distributed from Iquitos (Peru) to the south of Amazonas State, Brazil. Similar behavior was observed on eggplant (Aramendiz-Tatis et al., 2011), suggesting there to be an interchange of some seeds, which might include other species, in this region.

Cluster III (Figure 1, unbold square) included landraces ' 17 ' and ' 26 ' collecting from Manicoré-AM (Brazil) and Letícia (Colombia), respectively. Despite the large geographic distance between them $(>980 \mathrm{~km})$, they may be interchanging.

The last three clusters (IV, V and VI) showed to be exclusive to each country, '24' Jutaí-AM (Brasil); '27' Yurimaguas (Peru) and ' 8 ' Putumayo (Colombia) respectively. The higher genetic divergence among some Murupi landraces suggests there being a possibility for a significant heterotic effect in their crossings, enhancing the agronomical characters such as sweet pepper (C. annuum) (Gomide et al., 2003).

In conclusion, our findings point out that the 20 Amazonian Murupi chili pepper landraces may be clustered with at least six clusters; showing there to be genetic diversity in this region. Therefore, further efforts should be directed toward their conservation and breeding. Hybrid production may be the best and fastest Murupi chili pepper breeding method, because on the one hand in one generation can be grouped the better characteristics from two promising parents and on the other hand the heterotic effect can be used. 


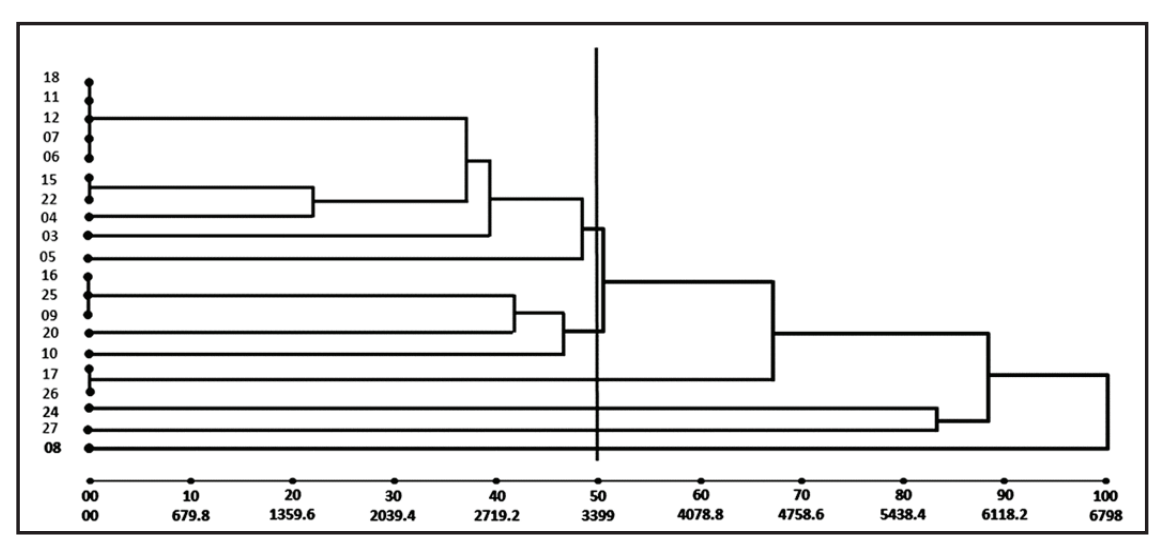

Figure 2. Dendogram for 20 Murupi chili pepper landraces, from the Amazon basin, obtained by a nearest neighbor clustering method based on generalized Mahalanobis distances. Cluster I: $18,11,12,07,06,15,22,04,03,05$; cluster II: 16, 25, 09, 20, 10; cluster III: 17 and 26; cluster IV: 24; cluster V: 27; cluster VI: 08. Manaus, INPA, 2013.

\section{ACKNOWLEDGEMENTS}

We express our sincere thanks to the institutional INPA project for the support provided to our research team, as well as to the Research Support Foundation of the State of Amazonas (FAPEAM) for the master scholarship granted to the first author.

\section{REFERENCES}

ANTONIOUS, GF; BERKE, T; JARRET, RL. 2009. Pungency in Capsicum chinense: variation among countries of origin. Journal of Environmental Science and Health 44: 179-184.

ARAMENDIZ-TATIS, H; SUDRÉ, CP; GONÇALVES, LSA; RODRIGUES, R. 2011. Potencial agronômico e divergência genética entre genótipos de berinjela nas condições do Caribe Colombiano. Horticultura Brasileira 29: $174-180$.

BATISTA, MRA; SILVA FILHO, DF; MARQUES, CMMC; CARDOSO, AAS. 2013. Seleção de populações de especies alternativas para uso na olericultura da Amazônia. In: NODA, H; SOUZA, LAG; SILVA FILHO, DF (orgs). Agricultura familiar no Amazonas: conservação dos recursos ambientais. Manaus: Wega, p.41-56.

BERTAN, I; CARVALHO, FIF; OLIVEIRA, AC; VIEIRA, EA; HARTWIG, I; SILVA, JAG; SHIMIDT, DAM; VALÉRIO, IP; BUSATO, CC; RIBEIRO, G. 2006. Comparação de métodos de agrupamento na representação da distância morfológica entre genótipos de trigo. Revista Brasileira de Agrociência 12: 279-286.
BOGUSZ JUNIOR, S; MARÇO, PH; VALDERRAMA, P; DAMASCENO, FC; ARANDA, MS; ZINI, CA; CARAMÃO, EB; MELO, AMT; TEIXIERA FILHO, J; GODOY, HT. 2015. Analysis of volatile compounds in Capsicum spp. by headspace solid-phase microextraction and GC x GC-TOFMS. Analytical Methods 7: 521-529.

BOGUSZ JUNIOR S; TAVARES FILHO AM; TEIXEIRA J; ZINI CA; GODOY HT. 2012. Analysis of the volatile compounds of Brazilian chilli peppers (Capsicum spp.) at two stages of maturity by solid phase microextraction and gas chromatography-mass spectrometry. Food Research International 48: 98-107.

COIMBRA, RR; MIRANDA, GV; CRUZ, CD; MELO, AV; ECKERT, FR. 2010. Caracterização e divergência genética de populações de milho resgatadas do Sudeste de Minas Gerais. Revista Ciência Agronômica 41: 159-166.

CRUZ, CD. Programa genes: diversidade genética. 2008. Viçosa: UFV. 278p.

CRUZ, CD; REGAZZI, AJ. Métodos biométricos aplicados ao melhoramento genético. 2001. Viçosa: UFV. 390p.

DOMENICO, CI; COUTINHO, JP; GODOY, HT; MELO, AMT. 2012. Caracterização agronômica e pungência em pimenta de cheiro. Horticultura Brasileira 30: 466-472.

FONSECA, RM; LOPES, R; BARROS, WS; LOPES, MTG; FERREIRA, FM. 2008. Morphologic characterization and genetic diversity of Capsicum chinense Jacq. accessions along the upper Rio Negro Amazonas. Crop Breeding and Applied Biotechnology 8: 187-194.

GOMIDE, ML; MALUF, WR; GOMES, LAA 2003. Heterose e capacidade combinatória de linhagens de pimentão (Capsicum annuum L.). Ciência e Agrotecnologia 27: 1007-1015.
IPGRI - International Plant Genetic Resources Institute. 1995. Descriptor for Capsicum (Capsicum spp.). Rome: International Plant Genetic Resource Institute. 49p.

JARRET, RL; BERKE, T. 2008. Variation for fruit morphological characteristics in a Capsicum chinense Jacq. germplasm collection. HortScience 43: 1694-1697.

KUREK, AJ; CARVALHO, FIF; CRUZ, PJ; LORENCETTI, C; CARGNIN, A; SIMIONI, D. 2002. Variabilidade em genótipos fixos de aveia branca estimada através de caracteres morfológicos. Revista Brasileira de Agrociência 8: 13-17.

LANNES, SD; FINGER, FL; SCHUELTER, AR; CASALI, VWD. 2007. Growth and quality of Brazilian accessions of Capsicum chinense fruits. Scientia Horticulture 112: 266-270.

NEITZKE, RS; BARBIERI, RL; RODRIGUES, WF; CORREAA, IV; CARVALHO, FIF. 2010. Dissimilaridade genética entre acessos de pimenta com potencial ornamental. Horticultura Brasileira 28: 47-53.

PEIXOTO, N; BRAZ, LT; BANZATTO, DA; MORAES, EA; MOREIRA, FM. 2002. Características agronômicas, produtividade, qualidade de vagens e divergência genética em feijão-vagem de crescimento indeterminado. Horticultura Brasileira 20: 447-451.

RIZZO, AAN; BRAZ, LT. 2000. Divergência genética entre cinco genótipos de melão rendilhado. Horticultura Brasileira 20: 171- 173.

SCARAZATI, B. 2016. Boletim agrometereológico 2013: Estação agroclimatológica da Embrapa Amazônia Ocidental no km 29 da rodovia AM10. Manaus: Embrapa Amazônia Ocidental. 35p (Documentos, 124).

SILVA FILHO, DF; OLIVEIRA, MC; SILVA, PC; MARTINS, LHP; NODA, H; MACHADO, FM. 2013. Análise morfológica e agronômica em etnovariedades de Capsicum, mantidas in situ, por populações tradicionais da Amazônia. In: NODA, H; SOUZA, LAG; SILVA FILHO, DF (orgs). Pesquisas agronômicas para a agricultura sustentável na Amazônia Central. Manaus: WEGA, p.61-72.

SUDRÉ, CP; RODRIGUES, R; RIVA, EM; KARASAWA, M; AMARAL JÚNIOR, AT. 2005. Divergência genética entre acessos de pimenta e pimentão utilizando técnicas multivariadas. Horticultura Brasileira 23: 22-27.

TOQUICA, SP; RODRÍGUEZ, F; MARTÍNEZ, E; DUQUE, MC; TOHME, J. 2003. Molecular characterization by AFLPs of Capsicum germplasm from the Amazon department in Colombia. Genetic Resources and Crop Evolution 50: 639-647.

ZEWDIE, Y; TONG, N; BOSLAND, P. 2004. Establishing a core collection of Capsicum using a cluster analysis with enlightened selection of accessions. Genetic Resources and Crop Evolution 51: 147-151. 